University of Nebraska - Lincoln

DigitalCommons@University of Nebraska - Lincoln

H. W. Manter Laboratory Library Materials

$9-1914$

Experimental Ingestion by Man of Cysticerci of Carnivore Tapeworms

Maurice C. Hall

United States Bureau of Animal Industry

Follow this and additional works at: https://digitalcommons.unl.edu/manterlibrary

Part of the Parasitology Commons

Hall, Maurice C., "Experimental Ingestion by Man of Cysticerci of Carnivore Tapeworms" (1914). H. W. Manter Laboratory Library Materials. 8.

https://digitalcommons.unl.edu/manterlibrary/8

This Article is brought to you for free and open access by DigitalCommons@University of Nebraska - Lincoln. It has been accepted for inclusion in H. W. Manter Laboratory Library Materials by an authorized administrator of DigitalCommons@University of Nebraska - Lincoln. 


\title{
EXPERIMENTAL INGESTION BY MAN OF CYSTICERCI OF CARNIVORE TAPEWORMS
}

\author{
Maurice C. Hali \\ Assistant Zoologist, U. S. Bureau of Animal Industry.
}

Having experimentally eaten the larvae of dog tapeworms on two occasions, I undertook to look up the literature on this subject in connection with the ingestion of Cysticercus pisiformis to check the frequently quoted record of $T$. pisiformis from man. I find that there are more cases of the sort than I had supposed, so I have collected these cases in connection with a recent similar case of my own.

Taenia pisiformis, under the name of $T$. serrata, has been recorded as a parasite of man by Vital (1874), who records, in effect, two cases. One was a case of intestinal taeniasis in a native Algerian, reported under the paragraph heading (translated) Two taenias in the digestive tract, one of which has the appearance of Taenia serrata. These tapeworms were collected post mortem. He states that one tapeworm was undoubtedly $T$. solium. The other was 1 meter long and $6 \mathrm{~mm}$. broad, the segments attached in such fashion as to present a saw-toothed aspect. The thick rostrum was armed with hooks, and a single lateral genital pore was noted in the segments. There are no further data on this case.

A footnote reference states that $T$. serrata has recently been collected at Constantine (the locality for Vital's case also) in company with two specimens of $T$. saginata from a young woman by the use of pumpkin-seed as a vermifuge. Parenthetically, he remarks that the worms were examined by Dr. Cauvet. Two months later, Cauvet pub lished in the same journal (Gazette médicale de Paris) a note on the tapeworms found in Algeria. In this note he lists and discusses Bothriocephalus, T. solium and T. saginata. He says nothing whatever about $T$. serrata, and it seems safe to assume that any statements he may have made regarding a worm from man being $T$. serrata were not based on careful examination and were not intended for publication.

It is quite impossible to identify $T$. serrata by any such casual method as Vital usèd. Parasitologists who have mentioned Vital's cases have regularly regarded them as doubtful or erroneous. Moniez (1896) states that neither Vital nor Cauvet can be considered as authorities. He adds that he has fed Cysticercus pisiformis to two volunteer human subjects without developing the tapeworm. GalliValerio (1898) states that he once ingested six of these larvae. This occasioned a slight stomachache that night, possibly due to toxins in the 
cysticerci, but no tapeworm development was noted in spite of fecal examination and the use of male fern as a vermifuge. During the summer of 1913 I ingested three Cysticercus pisiformis collected from a freshly killed rabbit. I did not ingest any of the cyst fluid and had no discomfort. There have been no indications of tapeworm development.

In view of the fact that ingestion of Cysticercus pisiformis by four persons has not resulted in tapeworm development in any case, and that Vital's and Cauvet's records show obvious evidence that there were no grounds for Vital's statement, it seems evident that his record of $T$. pisiformis should be distinctly characterized as erroneous.

Multiceps serialis has never been claimed as a parasite of man. Galli-Valerio (1909) states that he has eaten two larval scolices, and I recorded in 1910 the eating of three such scolices. No tapeworms developed in either case, indicating that the parasite will never be found as an accidental parasite of man. In passing, it may be said that on the face of it there would seem to be more likelihood of this parasite, which is frequently imbedded in the connective tissues in the edible musculature of the rabbit, functioning as a parasite of man than there is in the case of $T$. pisiformis where the fully developed larva is found among the inedible viscera.

Taenia teniaeformis has never been recorded as a parasite of man, but Krabbe (1880) has called attention to the fact that in Jutland, mice are sometimes chopped up, spread on bread and eaten raw as a folk remedy for retention of urine, and has suggested that this might lead to infestation with the adult worm. Moniez (1896) states that he has fed Cysticercus fasciolaris to his two volunteer subjects noted above without producing the adult tapeworm.

Taenia krabbei is another carnivore tapeworm that has not been reported from man, though its occurrence in the edible meat of an important food animal would indicate the likelihood of its occurring in man. However, Moniez (1896) states that his volunteers have ingested the larvae of this tapeworm without results.

Taenia tenella was surmised by Cobbold to be a human tapeworm arising from Cysticercus ovis in the meat of sheep. Railliet (1885) notes that Chatin has on several occasions ingested $C y$ sticercus ovis without giving rise to a tapeworm, and Ransom (1913) states that he has ingested ten of these larvae without result. The tapeworm produced by feeding Cysticercus ovis to dogs was considered by Chatin to be T. hydatigena, but Ransom (1913) has shown that it is a distinct species of carnivore tapeworm, Taenia ovis. The fact that Taenia ovis and Taenia krabbei, both with larvae situated in the edible musculature of important food animals, seem incapable of developing in man, is a 
further argument against the likelihood of such a tapeworm as T. pisiformis, with larvae in the inedible viscera, developing to an adult tapeworm in man.

Taenia hydatigena and Multiceps multiceps have never been reported as intestinal parasites of man. This is not surprising, in view of the size of the larvae and site of infection for the larvae. It is further likely that if they were present the former would be taken for $T$. solium and the latter for the more common $T$. pisiformis. I have found no records of the ingestion of the larvae by man, but Stiles (1898) states of the larvae of T. hydatigena, "Although several authors have attempted to infect themselves with tapeworms by swallowing this larvae, all such attempts have been negative."

The facts noted above indicate the correctness of the generally accepted view, that adult cestodes of the genus Taenia occurring in carnivores do not occur in man. The converse of this proposition is also true. 